\title{
Potential role for peroxisome proliferator-activated receptor $\gamma$ in regulating luteal lifespan in the rat
}

\author{
Nicole Tinfo and Carolyn Komar \\ Department of Animal Science, Iowa State University, Ames, lowa 50011, USA \\ Correspondence should be addressed to C Komar; Email: ckomar@iastate.edu
}

\begin{abstract}
Peroxisome proliferator-activated receptor $\gamma(\operatorname{PPAR} \gamma)$ has been shown to stimulate progesterone production by bovine luteal cells. We previously reported higher expression of PPAR $\gamma$ in old compared with new luteal tissue in the rat. The following studies were conducted to determine the role of PPAR $\gamma$ in rat corpora lutea $(C L)$ and test the hypothesis that PPAR $\gamma$ plays a role in the metabolism of progesterone and/or luteal lifespan. Ovaries were removed from naturally cycling rats throughout the estrous cycle, and pseudopregnant rats. mRNA for PPAR $\gamma$ and P450 side-chain cleavage (SCC) was localized in luteal tissue by in situ hybridization, and protein corresponding to PPAR $\gamma$ and macrophages identified by immunohistochemistry. Luteal tissue was cultured with agonists (ciglitazone, prostaglandin $\mathrm{J}_{2}$ ) or an antagonist (GW-9662) of PPAR $\gamma$. Progesterone was measured in media by RIA and levels of mRNA for 20 $\alpha$-hydroxysteriod dehydrogenase (HSD) and bcl-2 were measured in luteal tissue after culture by RT-PCR. An inverse relationship existed between the expression of mRNA for SCC and PPAR $\gamma$. There was no effect of PPAR $\gamma$ agonists or the antagonist on luteal progesterone production in vitro, or levels of mRNA for 20 $\alpha$-HSD. PPAR $\gamma$ protein was localized to the nuclei of luteal cells and did not correspond with the presence of macrophages. In new $\mathrm{CL}$, ciglitazone decreased mRNA for bcl-2 on proestrus, estrus, and metestrus. Interestingly, GW-9662 also decreased mRNA for bcl-2 on proestrus and diestrus in old and new $C L$, and on metestrus in new $C L$. These data indicate that PPAR $\gamma$ is not a major player in luteal progesterone production or metabolism but may be involved in regulating luteal lifespan.

Reproduction (2007) 133 187-196
\end{abstract}

\section{Introduction}

The peroxisome proliferator-activated receptors (PPARs) are transcription factors and members of the nuclear receptor superfamily. There are three isotypes of PPARs: PPAR $\alpha$, PPAR $\beta / \delta$, and PPAR $\gamma$. Ovarian tissue from several species, including humans (Lambe \& Tugwood 1996), pigs (Schoppe et al. 2002), sheep (Froment et al. 2003), mice (Cui et al. 2002), rats (Braissant et al. 1996, Komar et al. 2001), and cattle (Sundvold et al. 1997, Lohrke et al. 1998), expresses PPAR $\gamma$. Although this transcription factor has been detected in the ovaries of several species, to date very little is known regarding the role(s) of PPAR $\gamma$ in ovarian function.

Previous work from our laboratory, using the rat as a model, has shown that PPAR $\gamma$ is expressed primarily in granulosa cells and is downregulated in response to the luteinizing hormone (LH) surge (Komar etal. 2001). PPAR $\gamma$ was also identified in luteal tissue of the naturally cycling rat (Komar \& Curry 2002). Interestingly, the expression of mRNA for PPAR $\gamma$ was higher in luteal tissue from previous ovulations compared with luteal tissue forming from the most recent ovulation (Komar \& Curry 2002).
PPAR $\gamma$ is involved in processes that are critical to normal ovarian function such as angiogenesis (reviewed by Margeli et al. 2003), inflammation, and cell cycle control (reviewed by Berger \& Moller 2002), indicating that PPAR $\gamma$ may be an important player regulating ovarian gene expression. For example, cell death via apoptosis occurs in both ovarian follicles and corpora lutea $(\mathrm{CL})$. In the ovary, the anti-apoptotic gene, bcl-2, has been found to play a role in cell survival. The gene encoding bcl-2 contains a peroxisome proliferator response element (Butts et al. 2004), and therefore could be directly regulated by PPAR $\gamma$.

Another possible role for PPAR $\gamma$ in the ovary may be in the process of luteolysis. The expression of PPAR $\gamma$ is induced during the differentiation of monocytes into macrophages, and it is expressed in activated macrophages (Ricote et al. 1998, Tontonoz et al. 1998, Cunard et al. 2002). Macrophages accumulate in regressing $\mathrm{CL}$ in the rat from late proestrus to early estrus (Gaytan et al. 1998). These macrophages are thought to aid in the removal of luteal tissue by phagocytosis (reviewed by Niswender et al. 2000). Therefore, PPAR $\gamma$ may play a 
role in luteolysis via its presence in activated macrophages. Alternatively, PPAR $\gamma$ may be involved in luteal steroid production. In cattle, activation of PPAR $\gamma$ has been reported to stimulate progesterone production by the CL (Lohrke et al. 1998). Luteal tissue collected during the mid-phase of the bovine estrous cycle and cultured with an agonist of PPAR $\gamma$, prostaglandin $J_{2}$ $\left(\mathrm{PGJ}_{2}\right)$, secreted more progesterone than control tissue (Lohrke et al. 1998).

The objective of the current study was to determine the role of PPAR $\gamma$ in the rat CL. Given the ability of PPAR $\gamma$ agonists to affect progesterone production by bovine luteal cells, coupled with its expression pattern in the rat $\mathrm{CL}$, we hypothesized that PPAR $\gamma$ plays a role in luteal progesterone metabolism. Alternatively, due to its higher expression in old $\mathrm{CL}$ versus new $\mathrm{CL}$, and the fact that PPAR $\gamma$ is expressed in macrophages, which play a role in luteolysis, we also investigated the potential involvement of PPAR $\gamma$ in regulating the life cycle of the CL. Both the naturally cycling and pseudopregnant rats were used as models to assess the impact of PPAR $\gamma$ on progesterone production at various physiological stages. The naturally cycling rat allowed for investigating the role of PPAR $\gamma$ in both newly forming luteal tissue derived from the most recent ovulation and regressing luteal tissue present on the ovary from past ovulations. Since fully functional $C L$ do not develop in cycling rats, the pseudopregnant rat was used to investigate the role of PPAR $\gamma$ in functioning luteal tissue.

\section{Materials and Methods}

\section{Animals}

All animal procedures were approved by the lowa State University's Animal Care and Use Committee. Adult, female Sprague-Dawley rats were obtained from Harlan (Indianapolis, IN, USA), and kept on a $14 \mathrm{~h}$ light:10 h darkness cycle. Vaginal smears were taken daily to monitor the estrous cycle. Animals exhibiting three normal estrous cycles were used in the following experiments.

Ovaries were collected from naturally cycling rats to investigate the relationship between PPAR $\gamma$ and luteal progesterone production. In addition, the association of PPAR $\gamma$ and macrophages in luteal tissue was also investigated to determine if macrophages were the cells expressing PPAR $\gamma$ within the CL. Cycling rats were sacrificed on each day of the estrous cycle (proestrus, estrus, metestrus, and diestrus) between 0900 and $1000 \mathrm{~h}$. Ovaries were removed, cleaned of adnexa and frozen until processed for in situ hybridization, or fixed in $4 \%$ paraformaldehyde for immunohistochemical analysis, as described below. Luteal tissue was also established in culture as described below, to investigate how agonists and an antagonist of PPAR $\gamma$ impact progesterone production and catabolism.

The expression and function of PPAR $\gamma$ were also investigated in luteal tissue from pseudopregnant rats.
Rats were mated with a vasectomized male and sacrificed 10-16 days later ( $n=4$ animals). Luteal tissue was dissected from one ovary from each animal and cultured in vitro as described below. The second ovary from each animal was fixed in $4 \%$ paraformaldehyde and embedded in paraffin for immunohistochemical analysis.

\section{In situ hybridization}

Frozen ovarian tissue collected from rats on the days of proestrus, estrus, metestrus, and diestrus $(n=4$ animals/day) was serially sectioned at $10 \mu \mathrm{M}$. Consecutive tissue sections were used for localization of mRNA for P450 side-chain cleavage (SCC) and PPAR $\gamma$. Tissue sections were fixed in $4 \%$ paraformaldehyde and dehydrated by passing through a series of increasing ethanol solutions. Slides were placed in $2 \mathrm{mg} / \mathrm{ml}$ glycine in PBS ( $\mathrm{pH}$ 7.2), rinsed in PBS, followed by an incubation in $1.5 \%$ triethanolamine buffer with $0.25 \%$ acetic anhydride. Slides were subsequently treated with $2 \times$ SSC $(0.149 \mathrm{M}$ sodium chloride, $14.9 \mathrm{mM}$ sodium citrate, $\mathrm{pH}$ 7.0) and dehydrated by passing through a series of decreasing concentrations of ethanol.

Sense and antisense riboprobes for PPAR $\gamma$ and SCC (plasmids containing the cDNA for PPAR $\gamma$ and SCC were generously provided by Dr Walter Walhi, Universite de Lausanne, Lausanne, Switzerland and Dr J S Richards, Baylor College of Medicine, Houston, TX, USA respectively) were synthesized using a MAXISCRIPT kit (Ambion, Inc., Austin, TX, USA $)$ and $\alpha^{-}{ }^{35} \mathrm{~S}-$ UTP $(10 \mu \mathrm{mCi} / \mathrm{ml}$; ICN Biomedical, Inc., Irvine, CA, USA). Tissues were hybridized with radiolabeled probe $\left(1 \times 10^{6}\right.$ c.p.m. $)$ in $100 \mu \mathrm{l}$ hybridization buffer $(4 \mathrm{M} \mathrm{NaCl}, 1 \mathrm{M}$ Tris, $0.5 \mathrm{M}$ EDTA, 50x Denhardts, $25 \mathrm{mg} / \mathrm{ml}$ yeast tRNA, $10 \mathrm{mg} / \mathrm{ml}$ polyadenylic acid). After hybridization, slides were incubated in RNase solution 1 ( $2 \times$ SSC, $50 \%$ formamide, $0.1 \%$ $\beta$-mercaptoethanol), followed by incubation in RNase solution $2(0.5 \mathrm{M} \mathrm{NaCl}, 10 \mathrm{mM}$ Tris, $20 \mu \mathrm{g} / \mathrm{ml}$ RNase A). Slides were incubated in RNase solution 1 a second time, after which they were incubated in $0.1 \times$ SSC, $1 \%$ $\beta$-mercaptoethanol. Slides were dehydrated by rinsing with $30 \%$ ethanol containing $0.6 \mathrm{M} \mathrm{NaCl}, 60 \%$ ethanol containing $0.6 \mathrm{M} \mathrm{NaCl}, 80,95$, and $100 \%$ ethanol. The slides were air-dried, dipped in Kodak NTB2 emulsion and exposed at $4{ }^{\circ} \mathrm{C}$ for 1 week (SCC) or 4 weeks (PPAR $\gamma$ ). Slides were developed before being counterstained with hematoxylin. At least one slide was processed with the sense riboprobe and two slides with the antisense riboprobe (4 tissue sections/slide) per animal.

\section{Tissue culture}

Luteal tissue from ovaries collected throughout the estrous cycle was dissected from the ovary using 18-gauge needles. $C L$ from the current cycle (new) were 
differentiated from $\mathrm{CL}$ from previous cycles (old) by assessing the degree of vascularization (Fig. 1a). New CL were well vascularized, whereas $C L$ present on the ovary from past cycles were less vascularized (Bassette 1943). There was no attempt to discern the differences between old CL regarding how many cycles they had been present on the ovary. Individual CL were hemisected and cultured in $500 \mu \mathrm{l}$ of defined media (Dulbecco's modified Eagle's medium (DMEM): F12, 0.01\% sodium pyruvate, $0.22 \%$ sodium bicarbonate, $1 \%$ BSA, $0.125 \%$ gentamicin, and insulin-transferrin-sodium selenite media supplement; $\mathrm{pH}$ 7.2). In one experiment, CL from the day of estrus ( $n=5$ animals) were cultured in the presence or absence of the PPAR $\gamma$ agonists, ciglitazone $(65 \mu \mathrm{M})$ or PG $)_{2}(25 \mu \mathrm{M}$; Komar et al. 2001). Agents were added at the time tissues were established in culture and treatments were set up in duplicate. In a second experiment, luteal tissue from the days of proestrus, estrus, metestrus, and diestrus $(n=4$ animals/day of the cycle) was cultured with ciglitazone $(65 \mu \mathrm{M})$ or the PPAR $\gamma$ antagonist GW-9662 $(1 \mu \mathrm{M})$. The antagonist, GW-9662, was used because it has previously been shown that there is endogenous activity of PPAR $\gamma$ in the ovary (Froment et al. 2003, Lovekamp-Swan \& Chaffin 2005). Luteal tissue from pseudopregnant rats was also cultured with $\mathrm{PGJ}_{2}(25 \mu \mathrm{M})$ or GW-9662 $(1 \mu \mathrm{M})$. Tissues were incubated for $24 \mathrm{~h}$ at $37{ }^{\circ} \mathrm{C}$ in $5 \% \mathrm{CO}_{2}: 95 \%$ air. At the end of culture, media were collected and stored at $-20^{\circ} \mathrm{C}$ until analyzed by RIA for progesterone. Tissues were frozen and stored until used for RNA and DNA extraction. Concentrations of progesterone were corrected by amount of DNA/well. RNA quality was determined by formaldehyde/agarose gel electrophoresis at the end of culture.

\section{$\boldsymbol{R I A}$}

Concentrations of progesterone in conditioned media were determined as described previously (Komar et al. 2001). The intra- and inter-assay coefficients of variation were 2.3 and $13.9 \%$ respectively.
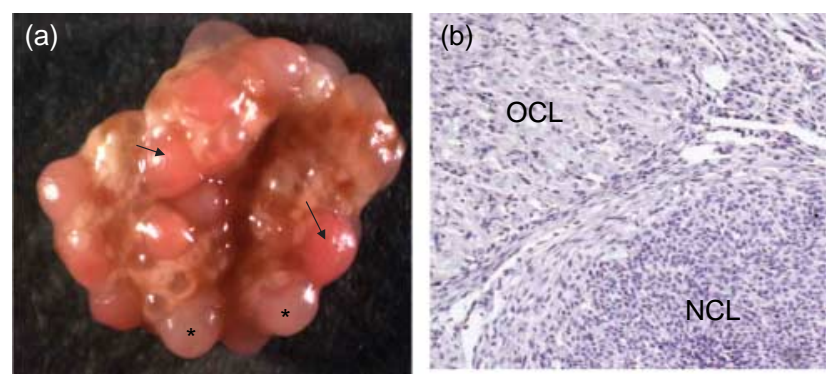

Figure 1 Image of an ovary collected on the day of metestrus from a naturally cycling rat. New luteal tissue is more vascularized than old luteal tissue (a). Arrows $(\rightarrow)$ denote new luteal tissue, asterisk $(*)$ denotes old luteal tissue. Histological image of old and new luteal tissues (b). OCL, old luteal tissue; NCL, new luteal tissue.

\section{PCR}

Total RNA was extracted from cultured tissues using Trizol reagent. cDNA was synthesized using SuperScript II Reverse Transcriptase and oligo (dT) random primers (Invitrogen). The cDNA obtained was analyzed by PCR to determine the expression of 20 $\alpha$-hydroxysteriod dehydrogenase $(20 \alpha-\mathrm{HSD})$ and bcl-2 in luteal tissue. S16 and glyceraldehyde-3-phosphate dehydrogenase $(\mathrm{GAPDH})$ were also analyzed and used as internal controls (Ko et al. 1999, Mendoza-Rodriguez et al. 2003). Primers utilized for 20 $\alpha$-HSD (Sugino et al. 1997), bcl-2, GAPDH (Mendoza-Rodriguez et al. 2003), and S16 (Ko et al. 1999) were published previously.

PCRs $(25 \mu \mathrm{l})$ for $20 \alpha$-HSD and S16 consisted of $2.5 \mathrm{mM} \mathrm{MgCl} 2,1 \mathrm{X}$ PCR buffer (200 mM Tris- $\mathrm{HCl}$, $500 \mathrm{mM} \mathrm{KCl}), 2 \mu \mathrm{M}$ of forward and reverse primers for both genes, $200 \mu \mathrm{M}$ dNTPs, 1.0 unit of Taq polymerase, $10 \times \mathrm{BSA}(\mathrm{BSA})$, and $50 \mathrm{ng}$ of cDNA. All amplifications were carried out for 30 cycles with denaturation at $95{ }^{\circ} \mathrm{C}$ for $2 \mathrm{~min}$, annealing at $65^{\circ} \mathrm{C}$ for $1 \mathrm{~min}$, and extension at $72{ }^{\circ} \mathrm{C}$ for $1 \mathrm{~min} /$ cycle.

Amplification reactions $(25 \mu \mathrm{l})$ for bcl-2 and GAPDH consisted of $20 \mathrm{mM}$ Tris- $\mathrm{HCl}(\mathrm{pH} 8.3), 50 \mathrm{mM} \mathrm{KCl}$, $1.0 \mathrm{mM} \mathrm{MgCl} 2,0.2 \mathrm{mM}$ dNTPs, $0.5 \mu \mathrm{M}$ forward and reverse primers for both bcl-2 and GAPDH, 2.5 units Taq DNA polymerase, $50 \mathrm{ng}$ cDNA for GAPDH, and $500 \mathrm{ng}$ cDNA for bcl-2. All amplifications were carried out for 35 cycles, with denaturation at $95^{\circ} \mathrm{C}$ for $5 \mathrm{~min}$, annealing at $60^{\circ} \mathrm{C}$ for $1 \mathrm{~min}$, and extension at $72{ }^{\circ} \mathrm{C}$ for 5 min per cycle.

Samples were analyzed in duplicate, and the analysis was repeated three times. PCR products were separated on a $2 \%$ agarose gel. Densitometric analysis of the resulting bands was conducted using the Spot Denso program (Fluorchem, Alpha Innotech, San Leandro, CA, USA). Relative levels of $20 \alpha-\mathrm{HSD}$ and bcl-2 were determined in relation to S16 and GAPDH respectively per sample.

\section{Immunohistochemistry}

Paraffin-embedded ovarian tissue was serially sectioned at $5 \mu \mathrm{m}$. Consecutive sections were processed for immunodetection of PPAR $\gamma$ and macrophages. Paraffin sections were dewaxed in xylene and rehydrated through a series of rinses in decreasing ethanol solutions. Antigen retrieval was performed by placing slides in $0.01 \mathrm{M}$ Tris $(\mathrm{pH}$ 8.5) in a microwave on high heat for $10 \mathrm{~min}$. After cooling, slides were placed in $1.5 \% \mathrm{H}_{2} \mathrm{O}_{2}$ in methanol to quench endogenous peroxidase activity. After rinsing with PBS (pH 7.2), slides were blocked with $10 \%$ normal horse (macrophage) or goat (PPAR $\gamma$ ) serum. Slides were then incubated with either a MAB against rat monocytes/macrophages (ED1 clone, Chemicon, Temecula, CA, USA) at a $1: 200$ dilution for $1 \mathrm{~h}$ at $37^{\circ} \mathrm{C}$ or an antibody against PPAR $\gamma$ (E8, Santa Cruz, CA, USA) at a 
1:50 dilution overnight at $4{ }^{\circ} \mathrm{C}$. Slides were rinsed with PBS and subsequently incubated with a species-specific biotinylated secondary antibody at a 1:200 dilution for macrophage detection (Vector Lab Inc., Burlingame, CA, USA) or 1:50 dilution for PPAR $\gamma$ detection (Amersham). Slides were rinsed in PBS and treated with an avidinperoxidase complex (ABC kit; Vector Lab Inc.). To visualize the immunocomplex, 3,3'-diaminobenzidine tetrahydrochloride was used. Slides processed for immunodetection of macrophages were counterstained with hematoxylin. All slides were mounted with Permount. For detection of both macrophages and PPAR $\gamma$, a minimum of one control slide (blocking serum used in place of primary antibody) and two treated slides were examined per rat (4 ovarian sections/slide).

\section{Statistical analysis}

Differences in levels of mRNA for $20 \alpha-\mathrm{HSD}$ and bcl-2 were analyzed by ANOVA (SAS Version 8.2, SAS Institute, Cary, NC, USA), followed by the StudentNewman-Keuls test for comparisons of multiple groups when appropriate (JMP 5.1). Concentrations of progesterone in conditioned media from old and new CL were log transformed and analyzed independently by ANOVA. A $P$-value $\leq 0.05$ was considered significant.

\section{Results}

To investigate the relationship between PPAR $\gamma$ and progesterone production, mRNAs for SCC and PPAR $\gamma$ were localized in luteal tissue from naturally cycling rats by in situ hybridization. New and old CL were differentiated histologically, with new $\mathrm{CL}$ containing more luteal cells and less stromal elements than old CL (Fig. 1b; Malven \& Sawyer 1966, Gaytan 1997, Simpson et al. 2001). An inverse relationship was observed between the expression of mRNA for SCC and PPAR $\gamma$. The expression of mRNA for SCC was higher in newly forming luteal tissue compared with that observed in old luteal tissue on all days of the cycle (Fig. 2). In contrast, the expression of mRNA for PPAR $\gamma$ was higher in old luteal tissue compared with newly forming luteal tissue (Fig. 3). The expression of mRNA for PPAR $\gamma$ appeared in a punctate pattern in some luteal tissue, most notably on the day of diestrus (Fig. 3j).
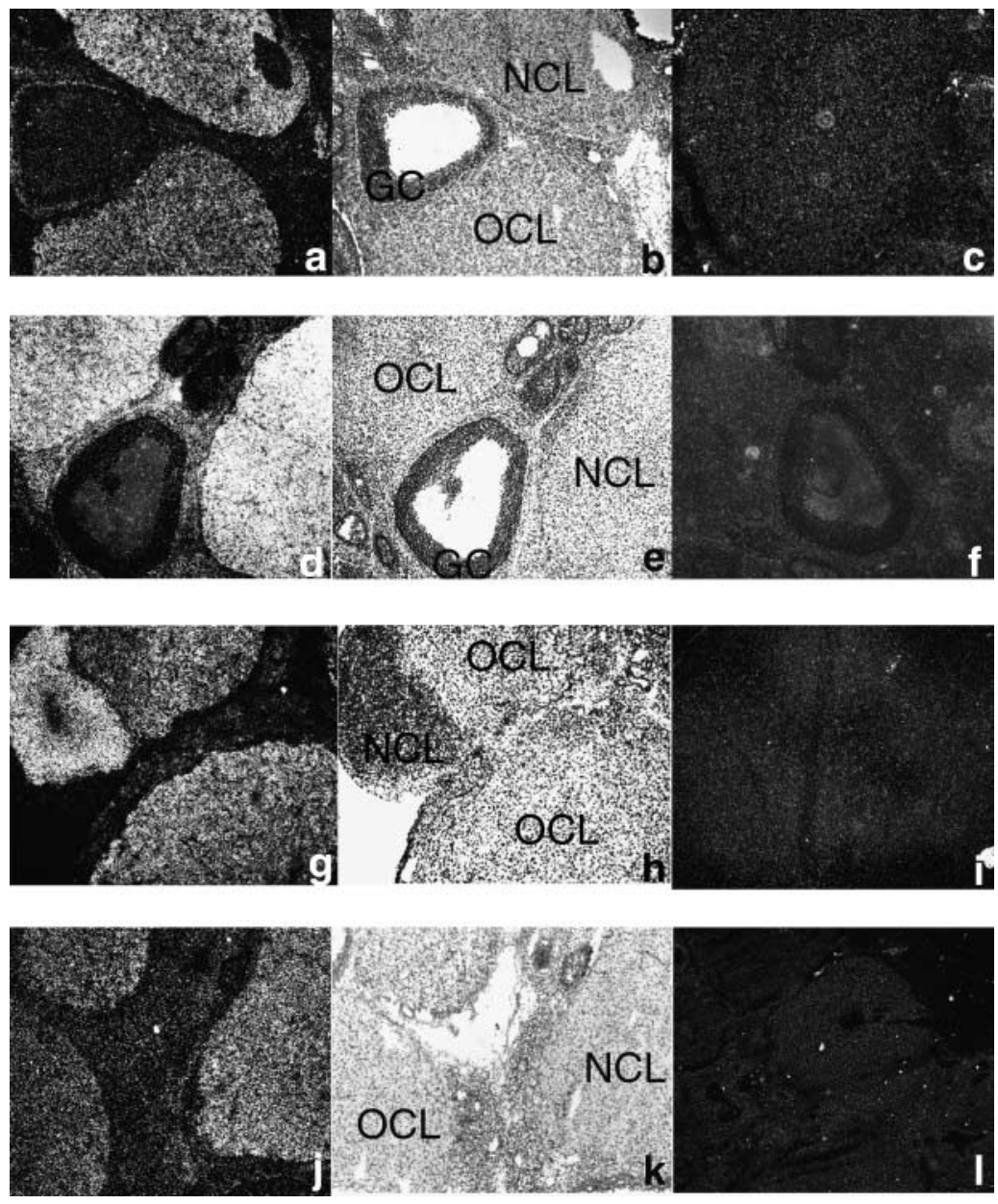

Figure 2 Localization of mRNA corresponding to SCC in ovarian tissue collected from rats on the day of proestrus ( $a, b$ and $c)$, estrus (d, e and f), metestrus ( $g$, $h$ and $\mathrm{i})$, and diestrus $(\mathrm{j}, \mathrm{k}$ and $\mathrm{I})$. Tissue sections $(10 \mu \mathrm{M})$ were hybridized with ${ }^{35}$ S-labeled sense and antisense riboprobes as described in the Materials and Methods. The first column represents darkfield images of ovarian tissue sections labeled with an antisense riboprobe $(a, d, g, j)$ with the corresponding brightfield image in the second column (b, e, h, k). Darkfield images of tissue hybridized with a sense riboprobe appear in the third column (c, f, i, I). GC, Granulosa cells; $\mathrm{OCL}$, old luteal tissue; $\mathrm{NCL}$, new luteal tissue; Original magnification, $100 \times$. 

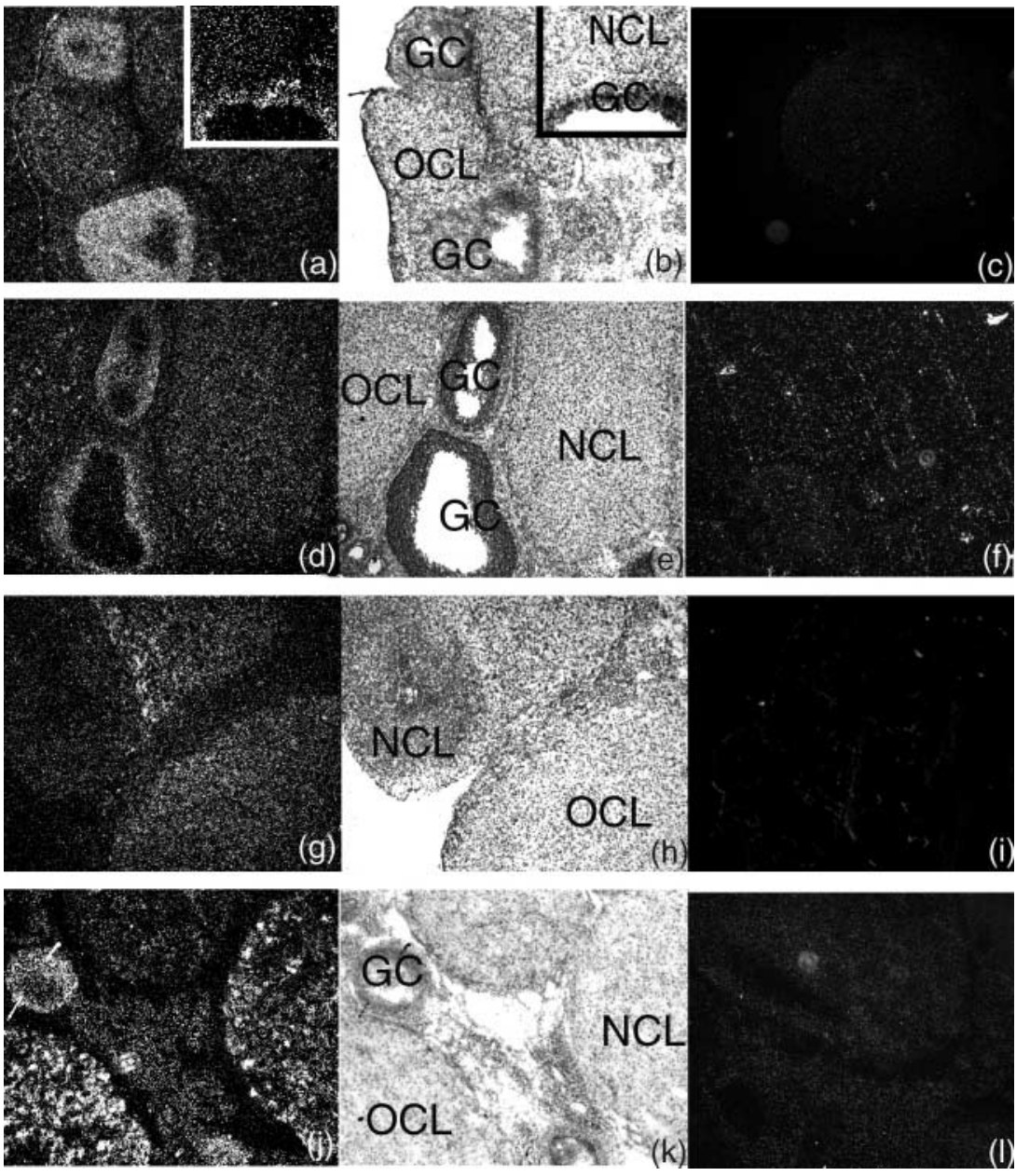

Figure 3 Localization of mRNA corresponding to PPAR $\gamma$ in ovarian tissue collected from rats on the day of proestrus ( $a, b$ and $c)$, estrus (d, e and $f$ ), metestrus ( $g, h$ and $i)$, and diestrus ( $j, k$ and $l)$. Panels $a$ and $b$ contain an inset image of a NCL from another area of the ovary for comparison. Tissue sections $(10 \mu \mathrm{M})$ were hybridized with ${ }^{35} \mathrm{~S}$-labeled sense and antisense riboprobes as described in the Materials and Methods. The first column represents darkfield images of ovarian tissue sections labeled with an antisense riboprobe $(a, d, g$, j) with the corresponding brightfield image in the second column (b, e, h, k). Darkfield images of tissue hybridized with a sense riboprobe appear in the third column (c, f, i, I). GC,

Granulosa cells; $\mathrm{OCL}$, old luteal tissue; $\mathrm{NCL}$, new luteal tissue; original magnification, $100 \times$.
Due to the inverse relationship between mRNA for SCC and PPAR $\gamma$ in luteal tissue with PPAR $\gamma$ being expressed at a higher level in old $C L$ versus new $C L$, we investigated the potential of PPAR $\gamma$ to influence the metabolism of progesterone. Levels of mRNA for $20 \alpha$-HSD, the enzyme responsible for the breakdown of progesterone into its inactive metabolite, were measured in luteal tissue collected on the day of estrus and cultured with ciglitazone or $\mathrm{PG} \mathrm{J}_{2}$. mRNA for $20 \alpha-H S D$ was expressed in new and old CL, but expression did not change in response to treatment with either PPAR $\gamma$ agonist (Fig. 4).

Luteal tissue from the days of proestrus, estrus, metestrus, and diestrus was cultured in vitro to determine how activation or inhibition of PPAR $\gamma$ would impact progesterone production throughout the estrous cycle. Old and new CL were separated and cultured with ciglitazone $(65 \mu \mathrm{M})$ or GW-9662 $(1 \mu \mathrm{M})$. There was no effect of activating or inhibiting PPAR $\gamma$ on progesterone production by new or old CL collected throughout the estrous cycle (Fig. 5a and b). However, administration of GW-9662 to old CL on proestrus tended to increase progesterone production compared with controls $(P=0.06$, Fig. $5 b)$. The secretion of progesterone in vitro by fully functional luteal tissue collected from pseudopregnant rats was also not affected by treatment with either PG) ${ }_{2}$ or GW-9662 (data not shown).
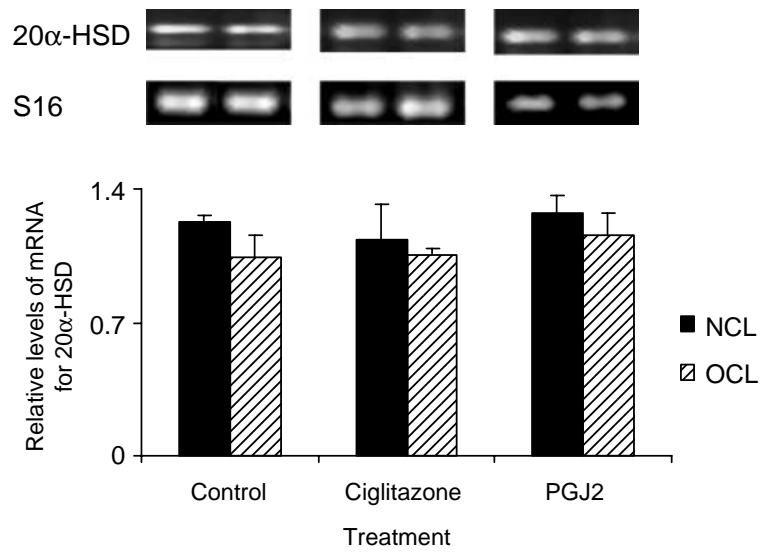

Figure 4 Relative levels of mRNA (mean \pm S.E.M.) for $20 \alpha$-HSD in rat luteal tissue on the day of estrus as described in the Materials and Methods. The image depicts PCR products for $20 \alpha-\mathrm{HSD}$ and S16 with corresponding levels of mRNA for $20 \alpha-\mathrm{HSD}$ in new and old $\mathrm{CL}$ cultured alone (control) or with ciglitazone $(65 \mu \mathrm{M})$ or $\mathrm{PGJ}_{2}(25 \mu \mathrm{M})$. $\mathrm{OCL}$, old luteal tissue, $\mathrm{NCL}$, new luteal tissue. 

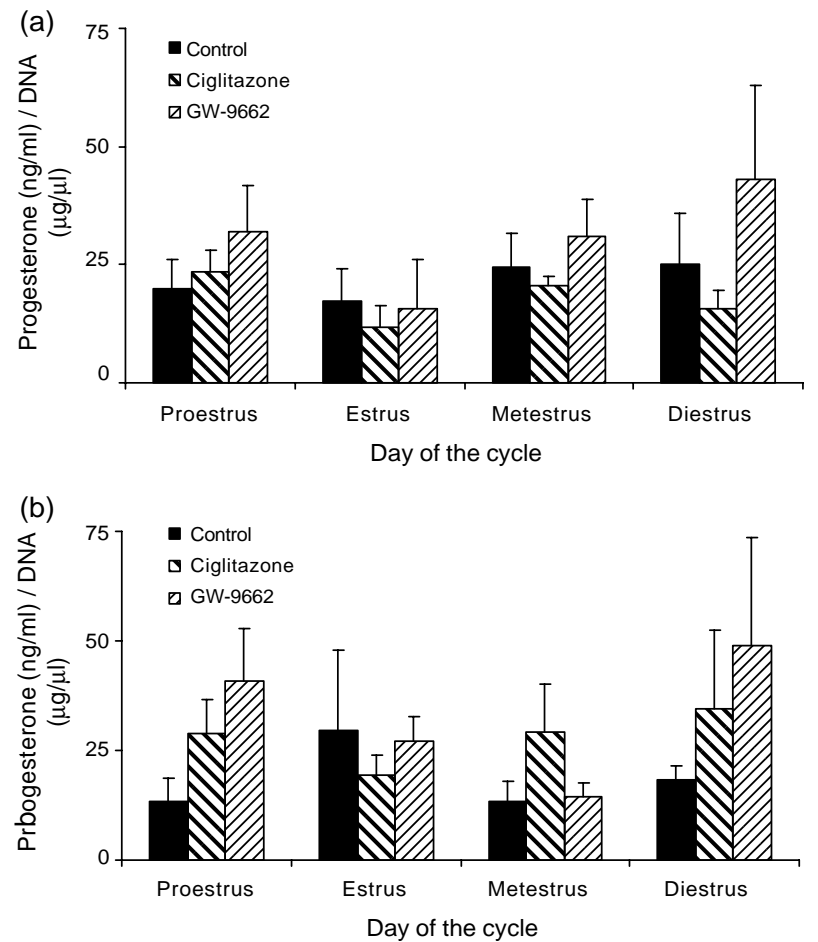

Figure 5 Progesterone production (mean \pm S.E.M.) by new (a) and old (b) luteal tissues collected from naturally cycling rats on all days of the cycle and cultured alone (control) or with ciglitazone $(65 \mu \mathrm{M})$ or GW-9662 (1 $\mu \mathrm{M})$.

PPAR $\gamma$ and macrophages were immunolocalized in serial tissue sections of ovaries collected throughout the cycle and during pseudopregnancy to determine if the expression of PPAR $\gamma$ in CL corresponded to macrophages within the tissue. Positive staining for ED1 (macrophages) was observed in luteal tissue from cycling (Fig. 6a-d) and pseudopregnant (Fig. 6e) rats. Luteal tissue on the day of diestrus contained low levels of labeling for ED1 (Fig. 6d) relative to the other days of the cycle. Protein corresponding to PPAR $\gamma$ was detected in the nuclei of luteal cells on all days of the cycle, albeit at a lower level than in granulosa cells of developing follicles (Fig. 7a). There was little if any co-localization of protein for PPAR $\gamma$ and macrophages (Fig. 7a-d). Protein corresponding to PPAR $\gamma$ was also observed in nuclei of luteal cells during pseudopregnancy at a relatively low level (data not shown).

The role of PPAR $\gamma$ in luteal lifespan was investigated by measuring levels of mRNA for bcl-2 in tissue collected throughout the cycle and cultured with ciglitazone or GW-9662. In newly forming luteal tissue collected on all days of the cycle except diestrus, treatment with ciglitazone reduced levels of mRNA for bcl-2 compared with controls (Fig. 8a, $P<0.05$, within day of the cycle). However, the administration of ciglitazone to old $\mathrm{CL}$ in vitro resulted in a decrease in levels of mRNA for bcl-2 only when the tissue was collected on the day of estrus (Fig. $8 b, P<0.05$, within
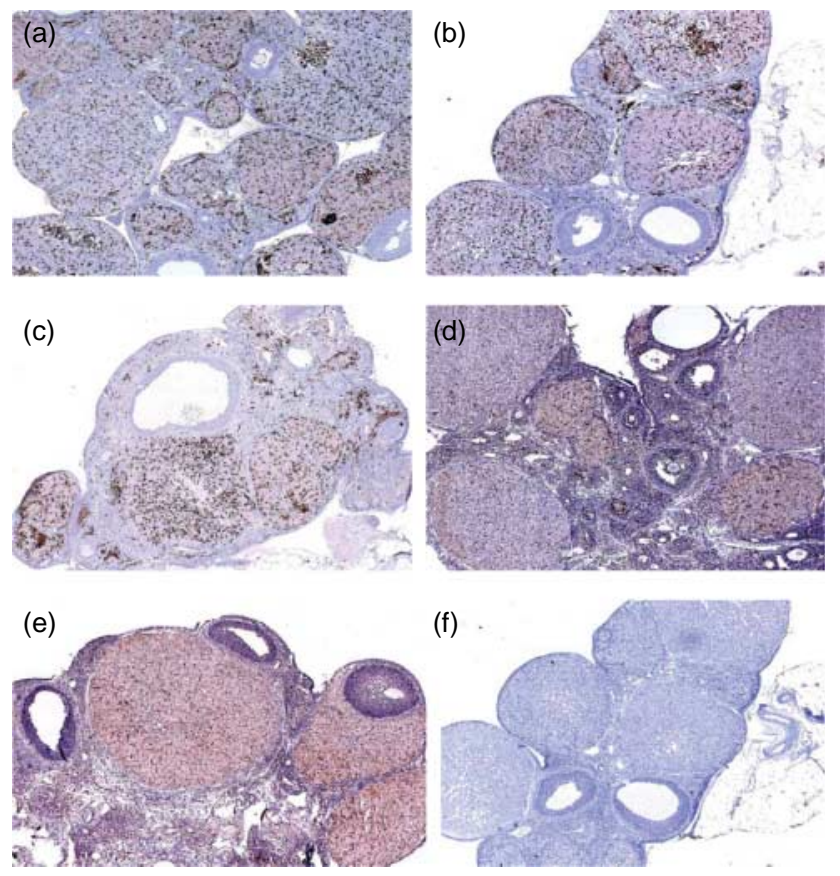

Figure 6 Immunodectection of macrophages (brown color) in sections of ovarian tissue collected from rats on proestrus (a), estrus (b), metestrus (c), diestrus (d), and during pseudopregnancy (e). Tissue section from an ovary collected on the day of proestrus with normal horse serum used in place of the primary antibody as a control (f). Original magnification, $50 \times$.

the day of the cycle). Interestingly, treating luteal tissue in vitro with the PPAR $\gamma$ antagonist, GW-9662, also reduced levels of mRNA for bcl-2 in both new and old $\mathrm{CL}$ collected on the days of proestrus and diestrus, as well as new CL collected on metestrus (Fig. 8a and b, $P<0.05$, within day of the cycle).
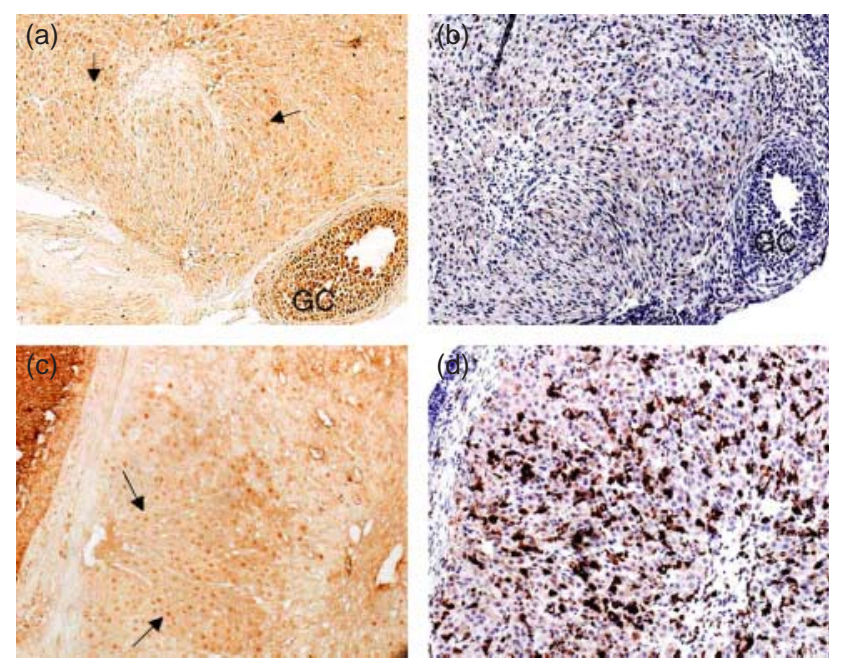

Figure 7 Immunodectection of PPAR $\gamma$ (a and c) and macrophages (b and d) in consecutive tissue sections of new ( $a$ and b) and old (c and d) $\mathrm{CL}$ in ovaries collected from rats on proestrus. Original magnification, $100 \times$. Arrows indicate labeling for PPAR $\gamma$ in the nuclei of luteal cells. GC, Granulosa cells. 
(a)

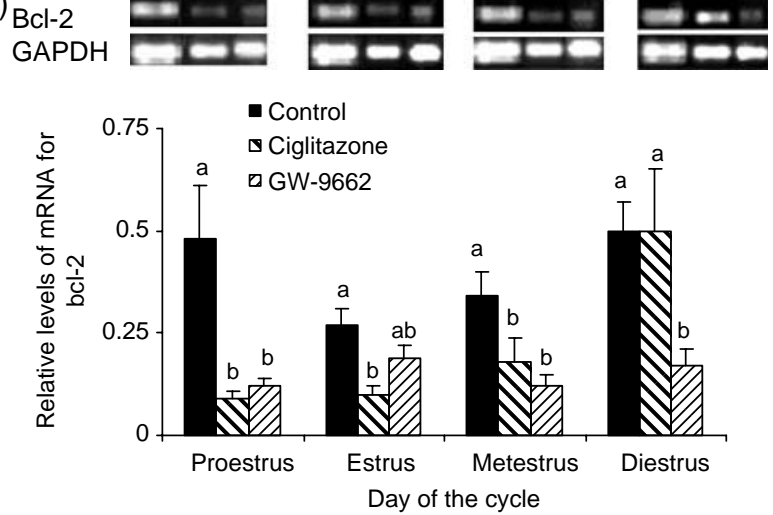

(b) $\mathrm{BCl}-2$

GAPDH
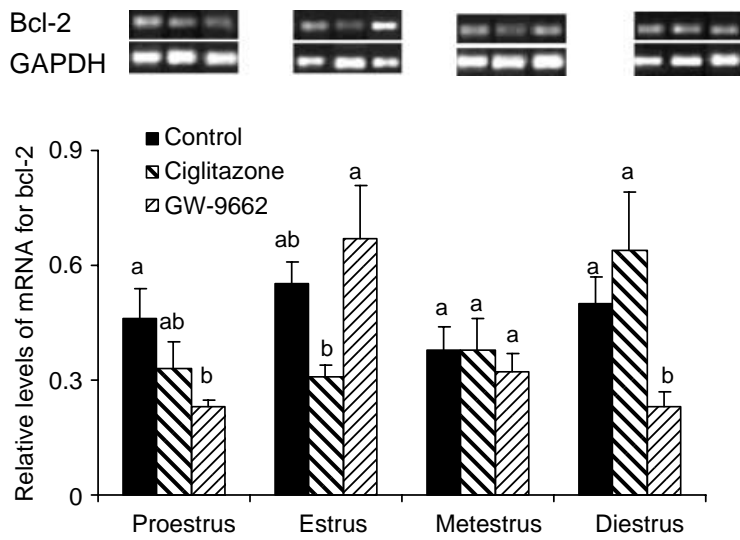

Proestrus zone

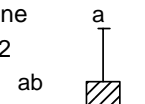

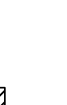

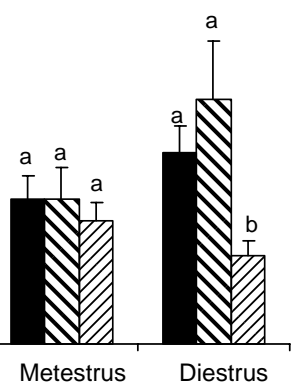

Day of the cycle

Figure 8 Relative levels of mRNA (mean \pm s.E.M.) for bcl-2 in rat luteal tissue collected throughout the cycle as described in the Materials and Methods. (a) PCR products for bcl-2 and GAPDH with corresponding levels of mRNA for bcl-2 in new CL cultured alone (control) or with ciglitazone $(65 \mu \mathrm{M})$ or GW-9662 $(1 \mu \mathrm{M})$. (b) PCR products for bcl-2 and $\mathrm{GAPDH}$ with corresponding levels of mRNA for bcl-2 in old CL cultured alone (control) or with ciglitazone $(65 \mu \mathrm{M})$ or GW-9662 $(1 \mu \mathrm{M})$. Bars with different superscripts denote significant differences within the day of the cycle $(P<0.05)$.

\section{Discussion}

$\operatorname{PPAR} \gamma$ has been detected in ovarian tissue from several species. However, at this time, it is unknown how this transcription factor impacts ovarian function. Research conducted by Cui et al. (2002) demonstrated that in transgenic mice with the expression of PPAR $\gamma$ disrupted in the ovary, the females were sub- or infertile. Since the expression of PPAR $\gamma$ was not disrupted in the uterus of these transgenic animals, the authors concluded that the lesion causing the sub- and infertility resided in the ovary. These authors reported that on the day of estrus, circulating concentrations of progesterone were 50\% lower in animals with PPAR $\gamma$ disrupted in the ovary compared with controls, although the difference was not significant most likely due to the small sample size $(n=4)$. In cattle, agonists of PPAR $\gamma$ were found to stimulate progesterone production from mid-phase luteal cells over a 24-h culture period (Lohrke et al.

1998). Treatment of human granulosa-lutein cells with $\mathrm{PGJ}_{2}$ had no effect on basal progesterone production, but inhibited $\mathrm{LH}$-stimulated progesterone production (Willis et al. 1999). Taken together, these data suggest that PPAR $\gamma$ may influence the ability of luteal tissue to produce progesterone, which is necessary for the establishment and maintenance of pregnancy.

The data presented here illustrate that PPAR $\gamma$ is not a major player in progesterone production in the rat $\mathrm{CL}$. In luteal tissue collected throughout the estrous cycle, as well as from pseudopregnant rats, there was no significant effect of PPAR $\gamma$ agonists or the antagonist on progesterone production. Our data also show that there is an inverse relationship between the expression of PPAR $\gamma$ in luteal tissue and the ability of that tissue to produce progesterone - as determined by levels of mRNA for SCC. These data agree with a previously published report on the gonadotropin-treated immature rat where an inverse relationship between the expression of mRNA for PPAR $\gamma$ and SCC in granulosa cells was detected during the periovulatory period (Komar \& Curry 2003). These findings indicate that downregulation of PPAR $\gamma$ may be important for the changes in gene expression involved in luteinization and the switch in steroid production from estrogen to progesterone in the rat. The finding in the current study that an antagonist of PPAR $\gamma$ tended to increase progesterone production by cultured luteal tissue further supports the hypothesis that downregulation of $\operatorname{PPAR} \gamma$ may be important for periovulatory progesterone production in the rat. These findings differ from those reported by Lohrke et al. (1998) and could be the result of differences in culture methods and/or species differences in luteal development and function. The current study utilized hemisected luteal tissue in vitro, whereas Lohrke et al. (1998) cultured dispersed luteal cells. Separation of large and small luteal cells alters steroidogenesis. Dispersed luteal cells produced lower amounts of hormones in vitro compared to intact tissue from the same CL (Pate \& Nephew 1988, Jaroszewski et al. 2003). Therefore, the use of intact luteal tissue provides a more accurate model of in vivo luteal function. In cycling rodents, mating or cervical stimulation is necessary for the development of fully functional corpora lutea. In contrast, after ovulation in cattle, luteal tissue develops regardless of whether the female is mated. The hormonal environment of the luteal phase also differs between the rat and cow. In the rat, the hormone prolactin is needed for luteal development and demise (reviewed by Freeman et al. 2000), while prolactin does not play a role in luteal function in cattle (reviewed by Niswender et al. 2000).

Another difference between the bovine and rat is that the rat ovary contains $\mathrm{CL}$ from past ovulations (old $\mathrm{CL}$ ) as well as $\mathrm{CL}$ from the most recent ovulation (new $\mathrm{CL}$ ). Multiple cycles are needed for the complete regression of old CL (reviewed by Freeman et al. 2000). This is in 
contrast to the bovine, whose luteal tissue develops from the most recent ovulation and regresses in the open animal before the next estrous cycle. In the rat, the secretion of progesterone from newly forming luteal tissue increases on the evening of proestrus. By diestrus, there is an increase in the activity of $20 \alpha-H S D$, the enzyme responsible for converting progesterone into its inactive metabolite, 20 $\alpha$-hydroxyprogesterone (Diaz et al. 2002). A decrease in progesterone may trigger the increase in expression of $20 \alpha-\mathrm{HSD}$, leading to progesterone catabolism (Stocco etal. 2001). In a study by Yoshida et al. (1999), the expression of $20 \alpha-H S D$ was higher in new luteal tissue collected at the end of pseudopregnancy compared with that at the beginning. This expression pattern of $20 \alpha-H S D$ most likely reflects the fact that at the beginning of pseudopregnancy, luteal tissue would secrete progesterone, which is needed for the establishment and maintenance of pregnancy, whereas at the end of pseudopregnancy a decline in progesterone would correspond with parturition at the end of gestation. In the current study, agonists of PPAR $\gamma$ had no effect on the expression of mRNA for $20 \alpha$-HSD in either new or old luteal tissue. These findings indicate that just as PPAR $\gamma$ is not a major player in progesterone production, it also does not affect the breakdown of progesterone via regulating the expression of mRNA for $20 \alpha$-HSD.

Regression of the $\mathrm{CL}$ involves functional (decrease in progesterone production) and structural changes (regression of luteal tissue, apoptosis, and macrophage infiltration) to the tissue. Accumulation of macrophages in $C L$ has been found to occur from the evening of proestrus to the morning of estrus in the rat (Gaytan et al. 1998). The current study examined the expression of macrophages in both the naturally cycling and pseudopregant rat models. In the cycling rat, prolactin is necessary for the establishment of the macrophage population in new luteal tissue as well as for the influx of monocytes and macrophages into regressing $\mathrm{CL}$ (Gaytan et al. 1997). Immunodetection of macrophages and PPAR $\gamma$ in serial sections of ovarian tissue demonstrated that they are localized primarily to different areas within luteal tissue. Macrophages were situated mostly around luteal cells, while PPAR $\gamma$ was detected in the nuclei of luteal cells. These findings are similar to those reported by Minge et al. (2006). These authors detected PPAR $\gamma$ in the nuclei of luteal cells in the mouse, and also reported co-localization of PPAR $\gamma$ with select macrophages present in the theca and stroma, as well as luteal tissue. The antibody employed in the study by Minge et al. (2006) identified recently recruited and mature macrophages, whereas the antibody utilized in the current study recognized both monocytes and macrophages. Since PPAR $\gamma$ is expressed in activated macrophages (Ricote et al. 1998, Tontonoz et al. 1998, Cunard et al. 2002), it would not co-localize with monocytes. Therefore, the detection of PPAR $\gamma$ in nuclei of luteal cells (current study; Minge et al. 2006), and limited co-localization with macrophages in luteal tissue (Minge et al. 2006), indicates that the higher expression of PPAR $\gamma$ in old compared with newly forming luteal tissue is not due solely to the presence of macrophages within the tissue.

Apoptosis, or programmed cell death, plays a role in luteal regression. Apoptosis is modulated by a number of regulatory genes, such as bcl-2. Bcl-2 is a member of the B-cell leukemia/lymphoma family, and plays a role in cell survival in the ovary. In the human and rodent, protein corresponding to bcl-2 has been detected in the corpus luteum and granulosa cells (reviewed by Richards 1994, Rodger et al. 1998, Leng et al. 2001, Kim \& Tilly 2004). As mentioned previously, the human gene encoding bcl-2 contains a peroxisome proliferator response element (Butts et al. 2004). Since bcl-2 and PPAR $\gamma$ are located in the same tissues within the ovary, PPAR $\gamma$ may affect ovarian cell survival via regulating the expression of bcl-2. In support of that hypothesis, a study using cultured granulosa cells showed that treatment with the PPAR $\gamma$ agonist, troglitazone, decreased protein levels for bcl-2 (Lovekamp-Swan \& Chaffin 2005). In the current study, levels of mRNA for bcl-2 in old $\mathrm{CL}$ were reduced by treatment with a $\operatorname{PPAR} \gamma$ agonist when the tissue was collected on the day of estrus, and by treatment with a PPAR $\gamma$ antagonist when tissue was collected on proestrus and diestrus. This reduction in mRNA for bcl-2 in response to both an agonist and antagonist of PPAR $\gamma$ was also seen in new $\mathrm{CL}$ collected on proestrus and metestrus. These apparent incongruous findings of both an agonist and antagonist of PPAR $\gamma$ inhibiting expression of mRNA for bcl-2 may be due to PPAR $\gamma$-dependent and -independent effects of these agents. Ciglitazone is a member of the thiazolidinedione (TZD) family of drugs. Troglitazone, another TZD, has been shown to have cellular effects that are not mediated by activation of PPAR $\gamma$ (Chawla et al. 2001), and reportedly can have direct effects on ovarian cells (Gasic et al. 2001). GW-9662 has also been shown to act as a PPAR $\gamma$ agonist in a normal human mammary epithelial cell line (Allred \& Kilgore 2005). Further study is warranted to determine how activation/inhibition of PPAR $\gamma$ impacts luteal cell survival.

In conclusion, our data suggest that PPAR $\gamma$ does not play a significant role in progesterone production in the naturally cycling or pseudopregnant rat. The expression pattern of PPAR $\gamma$ is inversely related to the ability of luteal tissue to produce progesterone, and agonists of $\operatorname{PPAR} \gamma$ had no effect on the ability of luteal tissue to secrete or breakdown progesterone. PPAR $\gamma$ is located in the nucleus of luteal cells where it may influence luteal cell survival via regulating the expression of bcl-2. Future studies are needed to further investigate the role of PPAR $\gamma$ in luteal cell apoptosis and how its varying expression is regulated during the lifespan of the CL. 


\section{Acknowledgements}

The authors thank Dr Walter Wahli for the plasmid containing the cDNA for PPAR $\gamma$ and Dr J S Richards for the SCC plasmid. We also thank Dr S Lamont for use of the PCR machine and Dr Steven Lonergan and Dr Elizabeth HuffLonergan for use of the Alpha Tech Imager. This project was supported by HD40842. The authors declare that there is no conflict of interest that would prejudice the impartiality of this scientific work.

\section{References}

Allred C \& Kilgore MW 2005 Selective activation of PPAR $\gamma$ in breast, colon, and lung cancer cell lines. Molecular and Cellular Endocrinology 235 21-29.

Bassette DL 1943 The changes in the vascular pattern of the ovary of the albino rat during the estrous cycle. American Journal of Anatomy $\mathbf{7 3}$ 251-291.

Berger J \& Moller DE 2002 The mechanisms of action of PPARs. Annual Review of Medicine 53 409-435.

Braissant O, Foufelle F, Scotto C, Dauca M \& Wahli W 1996 Differential expression of peroxisome proliferator-activated receptors (PPARs): tissue distribution of PPAR- $\alpha-\beta$ and $\gamma$ in the adult rat. Endocrinology 137 354-366.

Butts BD, Tran NL \& Briehl MM 2004 Identification of a functional peroxisome proliferator-activated receptor response element in the $3^{\prime}$ untranslated region of the human bcl-2 gene. International Journal of Oncology 24 1305-1310.

Chawla A, Barak Y, Nagy L, Liao D, Tontonoz P \& Evans RM 2001 PPAR $\gamma$ dependent and independent effects on macrophage-gene expression in lipid metabolism and inflammation. Nature 7 48-52.

Cui Y, Miyoshi K, Claudio E, Siebenlist UK, Gonzalez FJ, Flaws J, Wagner KU \& Hennighausen L 2002 Loss of the peroxisome proliferation-activated receptor $\gamma$ (PPAR $\gamma$ ) does not affect mammary development and propensity for tumor formation but leads to reduced fertility. Journal of Biological Chemistry 277 17830-17835.

Cunard R, Ricote M, DiCampli D, Archer CD, Kahn DA, Glass CK \& Kelly C 2002 Regulation of cytokine expression by ligands of peroxisome proliferator-activated receptors. Journal of Immunology 168 2795-2802.

Diaz FJ, Anderson LE, Wu YL, Rabot A, Tsai SJ \& Wiltbank MC 2002 Regulation of progesterone and prostaglandin $\mathrm{F}_{2}-\alpha$ production in the CL. Molecular and Cellular Endocrinology 191 65-80.

Freeman ME, Kanykska B, Lerant A \& Nagy G 2000 Prolactin: structure, function, and regulation of secretion. Physiological Reviews $\mathbf{8 0}$ 1523-1563.

Froment P, Fabre S, Dupont J, Pisselet C, Chesneau D, Staels B \& Monget P 2003 Expression and functional role of peroxisome proliferator-acivated receptor- $\gamma$ in ovarian folliculogenesis in the sheep. Biology of Reproduction 69 1665-1674.

Gasic S, Nagamani M, Green A \& Urban R 2001 Troglitazone is a competitive inhibitor of $3 \beta$-hydroxysteroid dehydrogenase enzyme in the ovary. American Journal of Obstetrics and Gynecology 184 575-579.

Gaytan F, Morales C, Bellido C, Aguila R \& Sanchez-Criado JE 1997 Role of prolactin in the regulation of macrophages and in the proliferative activity of vascular cells in newly formed and regressing rat corpora lutea. Biology of Reproduction 57 478-486.

Gaytan F, Bellido C, Morales C \& Sanchez-Criado JE 1998 Both prolactin and progesterone in proestrus are necessary for the induction of apoptosis in the regressing corpus luteum of the rat. Biology of Reproduction 59 1200-1206.
Jaroszewski JJ, Skarzynski DJ, Blair RM \& Hansel W 2003 Influence of nitric oxide on the secretory function of the bovine corpus luteum: dependence on cell composition and cell-to-cell communication. Experimental Biology and Medicine 228 741-748.

Kim MR \& Tilly JL 2004 Current concepts in Bcl-2 family member regulation of female germ cell development and survival. Biochimica et Biophysica Acta 1644 205-210.

Ko C, Yong-Ho IN \& Park-Sarge O 1999 Role of progesterone activation in pituitary adenylate cyclase activating polypeptide gene expression in rat ovary. Endocrinology 140 5185-5194.

Komar CM \& Curry TE Jr 2002 Localization and expression of messenger RNAs for the peroxisome proliferator-activated receptors in ovarian tissue from naturally cycling and pseudopregnant rats. Biology of Reproduction 66 1531-1539.

Komar CM \& Curry TE Jr 2003 Inverse relationship between the expression of messenger ribonucleic acid for peroxisome proliferator-activated receptor $\gamma$ and P450 side chain cleavage in the rat ovary. Biology of Reproduction 69 549-555.

Komar CM, Braissant O, Wahli W \& Curry TE Jr 2001 Expression and localization of PPARs in the rat ovary during follicular development and the periovulatory period. Endocrinology 142 4831-4838.

Lambe KG \& Tugwood JD 1996 A human peroxisome-proliferatoractivated receptor- $\gamma$ is activated by inducers of adipogenesis, including thiazolidinedione drugs. European Journal of Biochemistry 239 1-7.

Leng Y, Gu ZP \& Cao L 2000 Apoptosis induced by droloxifene and c-myc, bax, bcl-2 mRNA expression in cultured luteal cells of rats. European Journal of Pharmacology 409 123-131.

Lohrke B, Viergutz T, Shahi SK, Pohland R, Wollenhaupt K, Goldammer T, Walzel H \& Kanitz W 1998 Detection and functional characterization of the transcription factor peroxisome proliferatoractivated receptor $\gamma$ in lutein cells. Journal of Endocrinology 159 429-439.

Lovekamp-Swan T \& Chaffin CL 2005 The peroxisome proliferatoractivated receptor $\gamma$ ligand troglitazone induces apoptosis and p53 in rat granulosa cells. Molecular and Cellular Endocrinology 233 $15-24$.

Malven PV \& Sawyer CH 1966 A luteolytic action of prolactin in hypophysectomized rats. Endocrinology 79 268-274.

Margeli A, Kouraklis G \& Theocharis S 2003 Perxisome proliferatoractivated receptor- $\gamma$ (PPAR $\gamma$ ) ligands and angiogenesis. Angiogenesis 6 165-169.

Mendoza-Rodriguez CA, Monroy-Mendoza MG, Morimoto S \& Cerbon MA 2003 Pro-apoptotic signals of the bcl-2 gene family in the rat uterus occurs in the night before the day of estrus and precedes ovulation. Molecular and Cellular Endocrinology 208 31-39.

Minge CE, Ryan NK, Van Der Hoek KH, Robker RL \& Norman RJ 2006 Troglitazone regulates peroxisome proliferator-activated receptors and inducible nitric oxide synthase in murine ovarian macrophages. Biology of Reproduction 74 153-160.

Niswender G, Juengel J, Silva PJ, Rollyson M \& McIntush EW 2000 Mechanisms controlling the function and life span of the corpus luteum. Physiological Reviews 80 1-29.

Pate JL \& Nephew KP 1988 Effects of in vivo and in vitro administration of prostaglandin $\mathrm{F}_{2}-\alpha$ on lipoprotein utilization in cultured bovine luteal cells. Biology of Reproduction 38 568-576.

Richards JS 1994 Hormonal control of gene expression in the ovary. Endocrine Reviews 15 725-751.

Ricote M, Li AC, Willson TM, Kelly CJ \& Glass CK 1998 The peroxisome proliferator-activated receptor $\gamma$ is a negative regulator of macrophage activation. Nature 391 79-82.

Rodger FE, Fraser HM, Krajewski S \& Illingworth PJ 1998 Production of the proto-oncogene BAX does not vary with changing in luteal function in women. Molecular Human Reproduction 4 27-32.

Schoppe PD, Garmey JC \& Veldhuis JD 2002 Putative activation of the peroxisome proliferator-activated receptor $\gamma$ impairs androgen and enhances progesterone biosynthesis in primary cultures of porcine theca cells. Biology of Reproduction 66 190-198. 
Simpson KS, Byers MJ \& Curry TE Jr 2001 Spatiotemporal messenger ribonucleic acid expression of ovarian tissue inhibitors of metalloproteinases throughout the rat estrous cycle. Endocrinology 142 2058-2069.

Stocco CO, Chedrese J \& Deis RP 2001 Luteal expression of cytochrome $\mathrm{P} 450$ side-chain cleavage, steroidogenic acute regulatory protein, $3 \beta$-hydroxysteroid dehydrogenase, and $20 \alpha$-hydroxysteroid dehyrogenase genes in late pregnant rats: effects of luteinizing hormone an RU486. Biology of Reproduction 65 1114-1119.

Sugino N, Telleria CM \& Gibori G 1997 Progesterone inhibits 20 $\alpha$ hydroxysteroid dehydrogenase expression in the rat corpus luteum through the glucocorticoid receptor. Endocrinology 138 4497-4500.

Sundvold H, Brzozowska A \& Lien S 1997 Characterization of bovine peroxisome proliferator-activated receptors $\gamma 1$ and $\gamma 2$; genetic mapping and differential expression of the two isoforms. Biochemical and Biophysical Research Communications 239 857-861.
Tontonoz P, Nagy L, Alvarez JGA, Thomazy VA \& Evans RM 1998 PPAR $\gamma$ promotes monocyte/macrophage differentiation and uptake of oxidized LDL. Cell 93 241-252.

Willis DS, White J, Brosen J \& Frank S 1999 Effect of 15-deoxy-delta $(12,14)$-prostaglandin $J_{2}\left(\mathrm{PGJ}_{2}\right)$ a peroxisome proliferator activating receptor $\gamma$ (PPAR $\gamma$ ) ligand on human ovarian steroidogenesis. Proceedings from the Endocrine Society Annual Meeting, P3-247.

Yoshida S, Kubota K, Sasaki H, Hasegawa T, Nishihara M, Terada M \&

Takahashi M 1999 26-Cholesterol hydroxylase in rat corpora lutea: a negative regulator of progesterone secretion. Biology of Reproduction 61 557-562.

Received 5 August 2006

First decision 13 September 2006

Accepted 30 October 2006 